University of Nebraska - Lincoln

DigitalCommons@University of Nebraska - Lincoln

June 2004

FOOD RELOCATION BEHAVIOR AND SYNOPSIS OF THE

SOUTHERN SOUTH AMERICAN GENUS GLYPHODERUS

WESTWOOD (SCARABAEIDAE: SCARABAEINAE: EUCRANIINI)

Federico C. Ocampo

University of Nebraska - Lincoln, focampo2@unl.edu

Follow this and additional works at: https://digitalcommons.unl.edu/entomologypapers

Part of the Entomology Commons

Ocampo, Federico C., "FOOD RELOCATION BEHAVIOR AND SYNOPSIS OF THE SOUTHERN SOUTH

AMERICAN GENUS GLYPHODERUS WESTWOOD (SCARABAEIDAE: SCARABAEINAE: EUCRANIINI)" (2004). Papers in Entomology. 100.

https://digitalcommons.unl.edu/entomologypapers/100

This Article is brought to you for free and open access by the Museum, University of Nebraska State at DigitalCommons@University of Nebraska - Lincoln. It has been accepted for inclusion in Papers in Entomology by an authorized administrator of DigitalCommons@University of Nebraska - Lincoln. 


\title{
Food Relocation Behavior and Synopsis of the Southern South American Genus Glyphoderus Westwood (Scarabaeidae: Scarabaeinae: EucraniIni)
}

\author{
FEDERICO C. OCAMPO \\ Systematics Research Collections, W 436 Nebraska Hall \\ University of Nebraska State Museum \\ Lincoln, NE 68588-0514, U.S.A. \\ focampo@unlserve.unl.edu
}

\begin{abstract}
The Argentinean endemic Eucraniini genus Glyphoderus Westwood is redescribed, a key to species and a synopsis of the three known species, G. centralis Burmeister, G. monticola Burmeister, and G. sterquilinus (Westwood) is presented. The biology and food relocation behavior of the three species are described. A key to genera of the tribe Eucranini is also presented.
\end{abstract}

\section{Resumen}

El género Glyphoderus Westwood endémico de Argentina es redescripto y se presenta una clave para las especies y una sinopsis de las tres especies conocidas, $G$. centralis Burmeister, $G$. monticola Burmeister y G. sterquilinus (Westwood). La biología del género es discutida y el comportamineto de relocación del alimento de las tres especies es descripto. Se presenta una clave para los géneros de la tribu Eucraniini.

Glyphoderus Westwood is a small genus of the tribe Eucraniini (Scarabaeidae: Scarabaeinae). The Eucraniini is a unique tribe of dung beetles endemic to the Chaqueña and Monte biogeographic provinces in northwestern Argentina. The members of Eucraniini are unique in that they have very specialized ecological adaptations, exhibit unique behavior not seen in any other dung beetles, and occur only in specific desertthorn habitats of Argentina. The tribe consists of four genera: Anomiopsoides Blackwelder (five species), Ennearabdus Lansberge (one species), Eucranium Brullé (seven species), and Glyphoderus Westwood (three species) (Philips et al. 2002; Ocampo 2003, 2004). This paper is a continuation of my work on the taxonomy and the evolution of the food relocation behavior of the genera of Eucraniini.

Glyphoderus shares many derived character states with the genus Anomiopsoides (i.e., mesocoxae separated at base [Fig. 1c] and mesotarsus longer than metatarsus). Based on phylogenetic hypothesis, they are sister taxa (see Philips et al. 2002; Ocampo 2004; in prep.).

Nearly 250 specimens of Glyphoderus were studied for this work, $50 \%$ of which were originally misidentified or unidentified. This work provides a redescription of the genus Glyphoderus, including diagnosis, distribution, phenology, and illustrations of each species. A key to Eucraniini genera is also provided. These tools will prevent further misidentifications and misinterpretation of species distributions. The food relocation behavior of the three species of Glyphoderus is described.

Images and videos on the food relocation behavior and natural history of the tribe Eucraniini are available on the World Wide Web at http://www-museum.unl.edu/ research/entomology/Eucraniini/Eucraniinil.html (Ocampo 2003). 

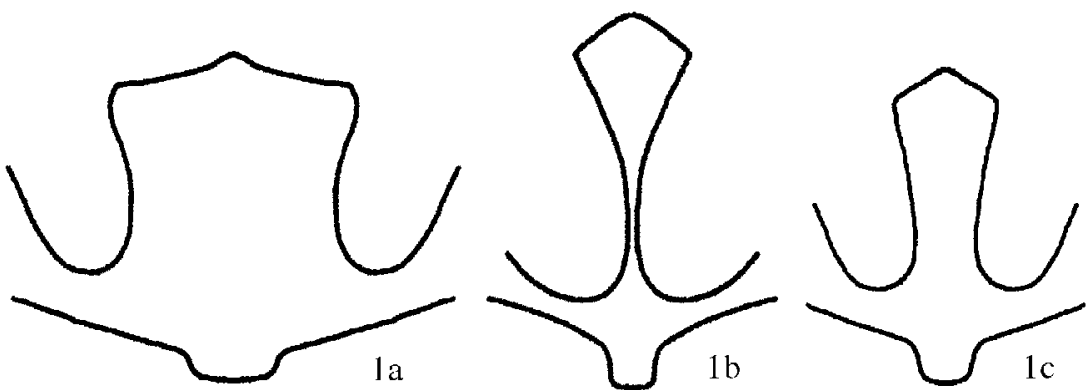

Fig. 1. Ventral view of metasternum. 1a) Ennearabdus Lansverge; 1b) Eucranium Dejean and; 1c) Anomiopsoides Balckwelder and Glyphoderus Westwood.

\section{Taxonomic History}

The genus Glyphoderus was described by Westwood in 1838 for one species, Anomiopsis sterquilinus Westwood 1837. Subsequently, Burmeister described two more species, Glyphoderus monticola in 1861 and Glyphoderus centralis in 1873. With the exception of being listed in catalogs (Gemminger and Harold 1869; Gillet 1911; Bruch 1911; Blackwelder 1944; Martínez 1956) little research has been done on this genus in the last 130 years. The life history of some species of the tribe Eucraniini was reported by Halffter and Matthews (1966), Halffter and Edmonds (1982), and Zunino et al. (1989, 1991). Zunino et al. (1991) studied the life history and reported their observations on the food relocation behavior of G. centralis. Colomba et al. (1996) characterized the mitotic chromosomes of $G$. sterquilinus.

\section{Material and Methods}

Observations on the biology and food relocation behavior of $G$. sterquilinus were carried out under natural conditions in Mendoza and La Rioja provinces, Argentina [Mendoza: Las Catitas. La Rioja: Olpas, Ulapes $(10 \mathrm{~km} \mathrm{~N})$, and Ulapes $(17 \mathrm{~km} \mathrm{~S})$ ], for a period of 15 days in January 2002 and five days in January 2003. Observations on the biology and food relocation behavior of $G$. monticola were carried out under natural conditions in La Rioja province [La Rioja $(20 \mathrm{~km} \mathrm{~N})$ ] for a period of five days in January 2002.

Body measurements, puncture density, puncture size, fovea density, fovea size, and density of setae are based on the following standards. Body length was measured from the apex of the pronotum (at the middle) to the apex of the elytra. Body width was measured across mid-pronotum. Puncture density was considered "dense" if punctures were nearly confluent to less than two puncture diameters apart, "moderately dense" if punctures were two to six diameters apart, and "sparse" if punctures were separated by more than six diameters apart. Puncture size was defined as "small" if punctures were $0.02 \mathrm{~mm}$ or smaller, "moderate" if $0.02-0.07 \mathrm{~mm}$, and "large" if $0.07 \mathrm{~mm}$ or larger. Surface was defined as "sparsely foveate" if there was (on average) a space of more than one diameter between foveae, "moderately dense" if there were $0.5-1$ diameters between foveae, and "densely foveate" if foveae were confluent or the space in between them was less than 0.5 diameters. Setae were defined as "sparse" if there were few setae, "moderately dense" if the surface was visible but with many setae, and "dense" if the surface was not visible through the setae. Elytral carinae were counted from the elytral suture. 
The phylogenetic species concept (Wheeler and Platnick 2000) was used to diagnose species: "species are the smallest aggregation of populations diagnosable by a unique combination of characters."

The results of this study were based on specimens from the following institutions and collections. The collections and their acronyms are as follows.

AMNH: American Museum of Natural History, New York, NY (L. Herman).

CMNC: Canadian Museum of Nature, Ottawa, Canada (R. S. Anderson, F. Génier).

CNCI: Canadian National Collection of Insects, Ottawa, Canada (A. Davies).

FCOC: Federico Carlos Ocampo Collection. Buenos Aires, Argentina.

HAHC: Henry and Anne Howden Collection, Ottawa, Canada (H. Howden).

HECO: Hope Entomological Collections Oxford, England (D. J. Mann).

IADIZA: Instituto Argentino de Investigaciones de Zonas Aridas (S. Roig-Juñent).

MACN: Museo Argentino de Ciencias Naturales, Buenos Aires, Argentina (A. Bachmann).

MLPA: Museo de La Plata, La Plata, Argentina (J. Schnack).

MLUH: Martin-Luther-Universität, Zoologisches Institut, Halle, Germany (Karla Schneider).

MNHN: Muséum National d'Historie Naturelle, Paris, France (Jean Menier).

UNSM: University of Nebraska State Museum, Lincoln, NE (B. Ratcliffe, M. L. Jameson).

USNM: United States National Museum, Washington D. C. (Nancy Adams).

\section{Key to Genera of Eucraniini}

1 Hind wings obsolete. Mesosternum narrow between mesocoxae (Fig. 1b-1c) … 2

$1^{\prime}$ Hind wings fully developed. Mesosternum wide between mesocoxae (Fig. 1a) Ennearabdus Lansverge

2 Mesocoxae separated at base (Fig. 1c). Mesotarsus longer than metatarsus ....... 3

2' Mesocoxae nearly contiguous at base (Fig. 1b). Mesotarsus shorter than

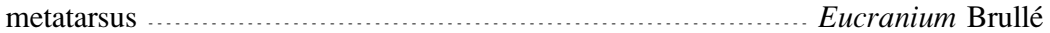

3 Pronotum lacking horns or large medial depression (males and females). Clypeus with 2 well-developed medial processes; processes as long or longer than length of

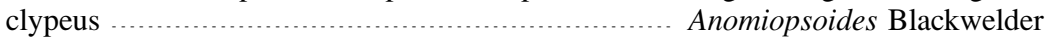

3' Pronotum with horns and large medial depression (males), or with large medial depression (females). Clypeus with 2 medial processes; processes shorter than length of clypeus Glyphoderus Westwood

\section{Clave para los Géneros de Eucraniini}

1 Alas posteriors obsoletas (no voladores). Mesoesterno angosto entre las mesocoxas (Fig. 1b-1c)

1' Alas posteriors bien desarrolladads. Mesosterno ancho entre las mesocoxas (Fig. 1a)

Ennearabdus Lansverge

2 Mesocoxas separadas en la base (Fig. 5c). Mesotarso más largo que metatarso ... 3

$2^{\prime}$ Mesocoxas contiguas en la base (Fig. 5b). Mesotarso más corto que metatarso

Eucranium Brullé

3 Pronoto sin cuernos o gran surco medio (machos y hembras). Clípeo con dos procesos medianos bien desarrollados; procesos tan largos o más que el largo del resto del clípeo Anomiopsoides Blackwelder

3' Pronoto con cuernos y gran surco medio (machos) o surco medio (hembras). Clípeo con dos procesos medinaos más cortos el resto del clípeo 


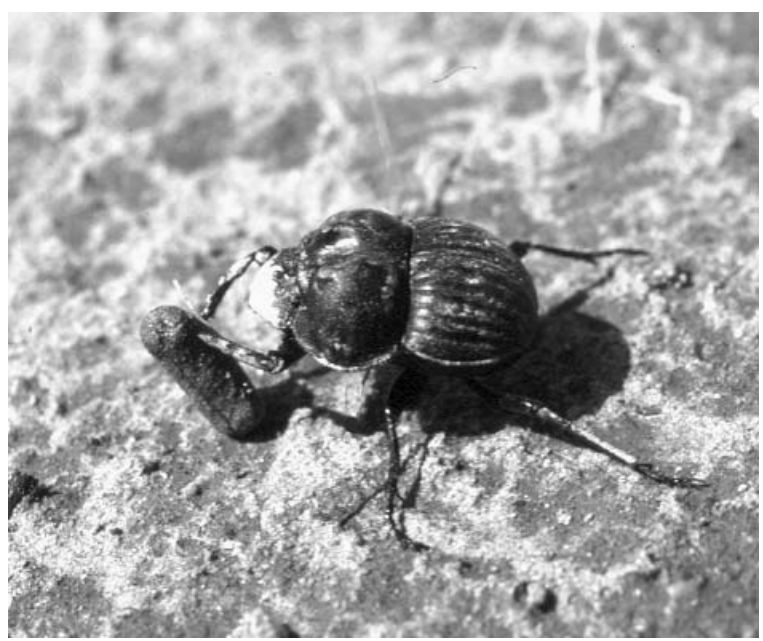

Fig. 2. Female of Glyphoderus sterquilinus (Westwood) carrying a rodent dung pellet.

\section{Glyphoderus Westwood, 1838}

(Figs. 1c, 2-6)

Glyphoderus Westwood, 1838:163. Glyphiderus, Westwood 1838:164.

Type species. Anomiopsis sterquilinus Westwood 1837, here designated.

Description. Form (Fig. 4): Color black; body globose, sides rounded. Size small to medium (length $9.5-22.5 \mathrm{~mm}$; width $6.5-14.5 \mathrm{~mm}$ ). Head: Surface punctate to densely foveate; form trapezoidal, wider than long. Frons biconcave or slightly convex; Frontoclypeal suture present, complete, with or without small tubercle in middle. Clypeus well developed (Fig. 4) with two medial processes and variable number of denticles; denticles large or small, rounded or acute. Clypeal disc with (males) or without (females) depression in middle. Gena with external margin denticulate or irregularly denticulate. Eyes small, completely divided by gena, halves subequal in size. Antenna 9-segmented. Segment 1 as long as 2-6 combined. Club 3-segmented, elongated, with a distinct glabrous area on external surface of first segment. Pronotum (Figs. 3-5): Transverse, convex; sexual dimorphism present; with 4 horns or tubercles and $1 \mathrm{~T}$-shaped, anterio-medial horn (males) and with deep, wide, longitudinal depression or only with deep, wide, longitudinal depression (females); horns, tubercles, and depression variably developed. Lateral fovea present, rounded or elongated. All margins beaded; lateral margins rounded, densely setose, setae long; posterior margin slightly sinuous. Posterior angle right, with distinct flat area. Elytron (Fig. 4): Globose. Surface with 8 variably impressed striae; with pseudoepipleura well developed at level of 7th elytral stria. Disc with intervals with minute tubercles. Hind wings: Obsolete. Venter: Proepisternum convex, shining, sparsely setose. Prosternum with posterior margin slightly pointed. Mesosternum transverse; mesometasternal suture broadely arcuate, concave in middle. Metasternum length 4.40-4.50 times width at middle. Abdominal sternites 2-6 with sutures distinct; sternite 5 more narrow in middle in males than in females; sternite 6 strongly narrow in middle (males and females). Legs: Mesocoxae subparallel, slightly convergent posteriorly, separated at base (Fig. 1c). Protibial dorsal surface punctate to foveate, with dorsomedial fringe of setae; external margin with four teeth; teeth with acute or rounded apex; apical margin oblique, truncate; protibial spur straight or curved at apex. Protarsi absent. Meso and metatibiae slender; with 2 dorsal and 1 ventral fringe of setae, setae arising from base of small denticles; apex expanded, with a fringe of setae on margin. Mesotibia with 2 spurs, medial spur longer than external. Mesotarsus longer than 


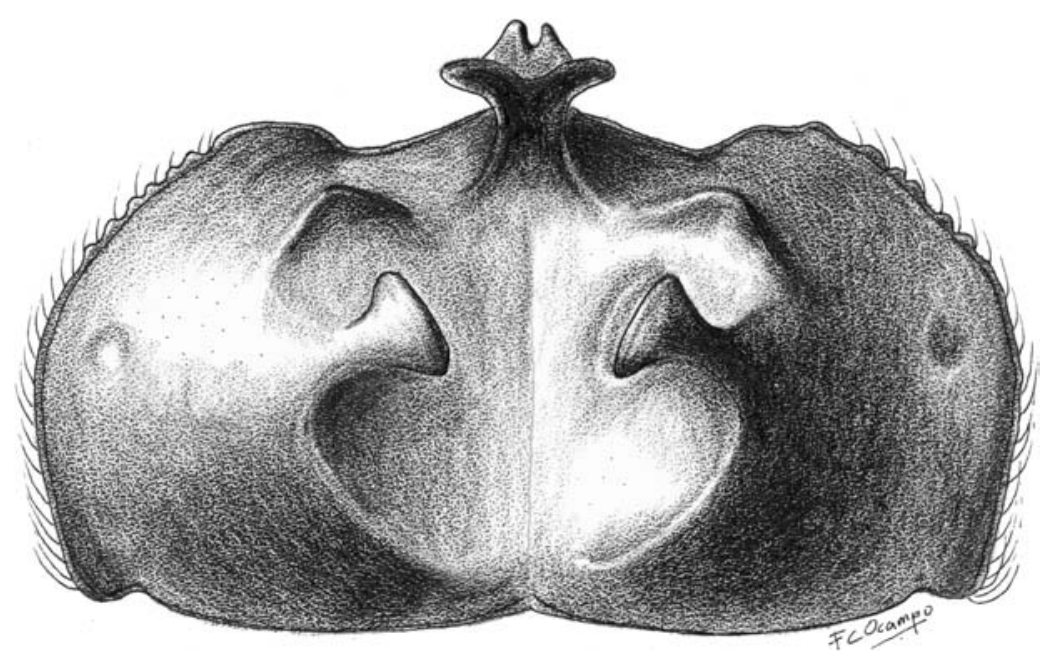

Fig. 3. Dorsal view of the pronotum of Glyphoderus centralis Burmeister.

metatarsus. Metatibia with 1 spur. Meso- and metatarsi unequal in size, becoming gracile toward apex, with apex setose. Tarsal claws absent. Male genitalia: Symmetrical, variably sclerotized.

Diagnosis. The following characters will separate Glyphoderus from all other Scarabaeinae in the New World: clypeus with four anterior processes; pronotum with horns, tubercles, or a deep, wide depression (Figs. 3-5); mesocoxae not contiguous at the base (Fig. 1); legs slender; protibia with four teeth; meso- and metatibial apex expanded; protarsi absent; mesotarsus longer than metatarsus; and hind wings obsolete.

Natural History and Food Relocation Behavior. The genus Glyphoderus is restricted the Monte and southeastern Chacoan biogeographic provinces in northeastern Argentina from $26^{\circ}$ to $34^{\circ} \mathrm{S}$ latitude and between $150-1,850 \mathrm{~m}$ altitude. The climate in these areas is temperate-arid with very little rainfall (between $80-250 \mathrm{~mm}$ per year) (Roig-Juñent et al. 2001). The northern and central regions of the Monte province receive rains in the summer, but the south is colder and rainfall is distributed throughout the year (Morello 1958; Cabrera 1976). The dominant vegetation of this region is a fairly continuous layer of shrubs and grass that, at times, can be very open. The landscape consists of sandy plains, and is characterized by the presence of mountain chains that define several, longitudinal valleys.

The results of behavioral observations and natural history of G. monticola and $G$. sterquilinus are very similar to those of $G$. centralis, but are described separately because the first two species observations were carried out by the author whereas the observation of G. centralis was conducted by Zunino et al. (1989).

Under natural conditions, the period of surface activity of $G$. monticola and $G$. sterquilinus is from 9:30 am to 1:00 pm, and from 5:00 pm to 7:00 pm, depending on atmospheric and soil temperature. No nocturnal, surface activity was recorded. During the observations atmospheric temperature varied between $21-40^{\circ} \mathrm{C}$ in the shade. Both species prefer open sandy or clay soils with a $20-60 \%$ vegetation cover. Glyphoderus sterquilinus and G. monticola, as do most of the Eucraniini, specialize on dehydrated dung pellets. Specimens were observed carrying pellets of "vizcacha" (Lagostomus maximus (Desmarest)), "cuis chico", (Microcavia australis (Geoffroy Saint-Hilaire \& D' Orbigny)), and goat. Specimens of G. sterquilinus did not take dry horse or cow 


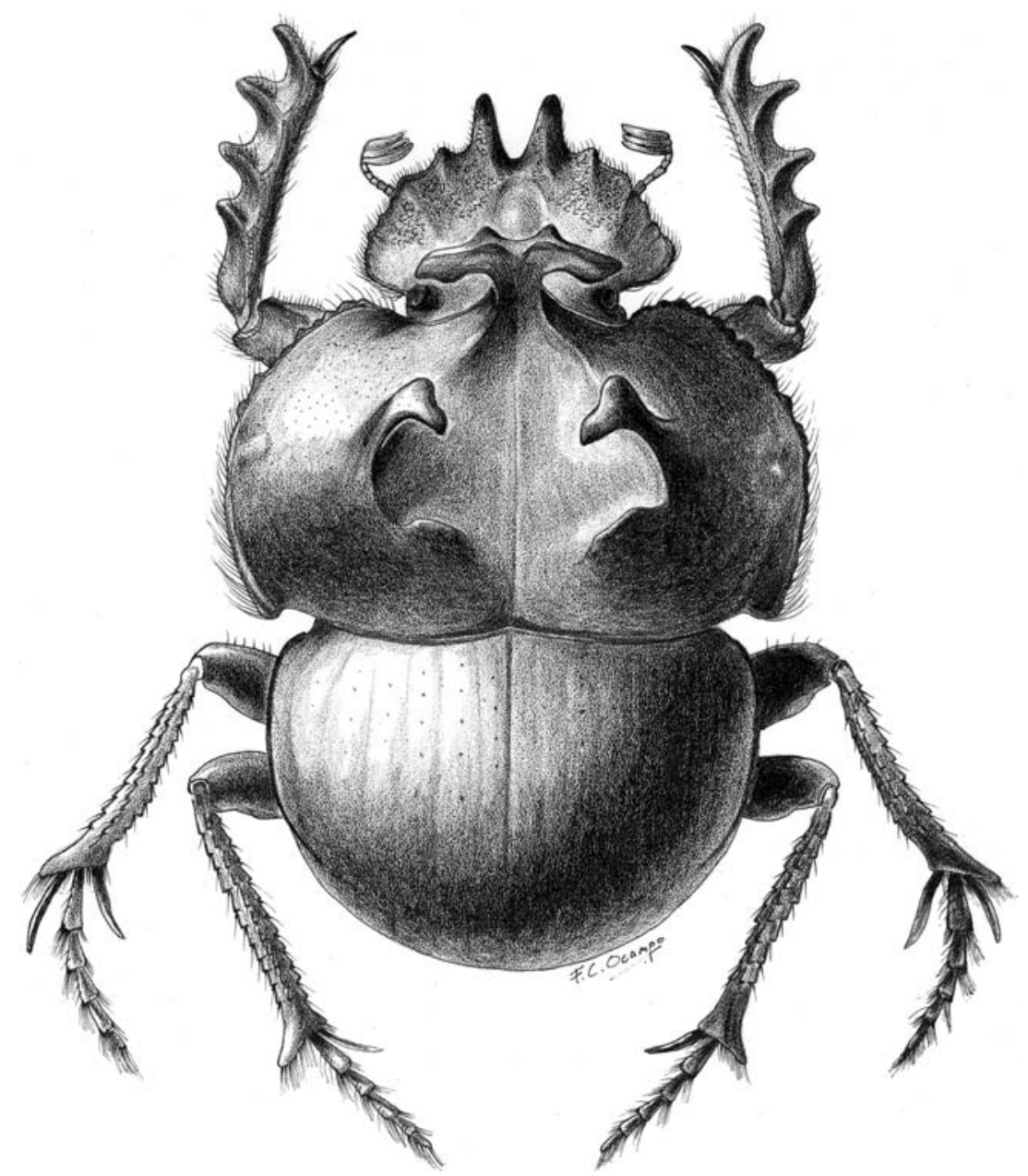

Fig. 4. Dorsal habitus of Glyphoderus monticola Burmeister.

dung even when it was offered, and they were not attracted to dung traps baited with fresh human or cow dung. When foraging, they run on four legs, keeping their forelegs motionless and in a horizontal position with respect to the surface. Adults run in zig-zags or do not follow any particular direction from their burrow (apparently searching randomly). To carry food, the beetles grasp it with the foretibiae and run forward using only their middle and hind legs (Fig. 2), this behavior is known only for members of the tribe Eucraniini. It is not clear how the beetles find their way back to the burrow. As described by Byrne et al. (2003) and Dacke and Warrant (2002) for the South African flightless dung beetles Scarabaeus rugosus (Hausman), S. rusticus (Boheman), Kheper nigroaeneus (Boheman) and Pachylomerus femoralis (Kirby) (Scarabaeinae: Scarabaeini) Glyphoderus species must rely on cues such as the pattern of polarized light. Beetles may use polarized light as a compass bearing that can be 


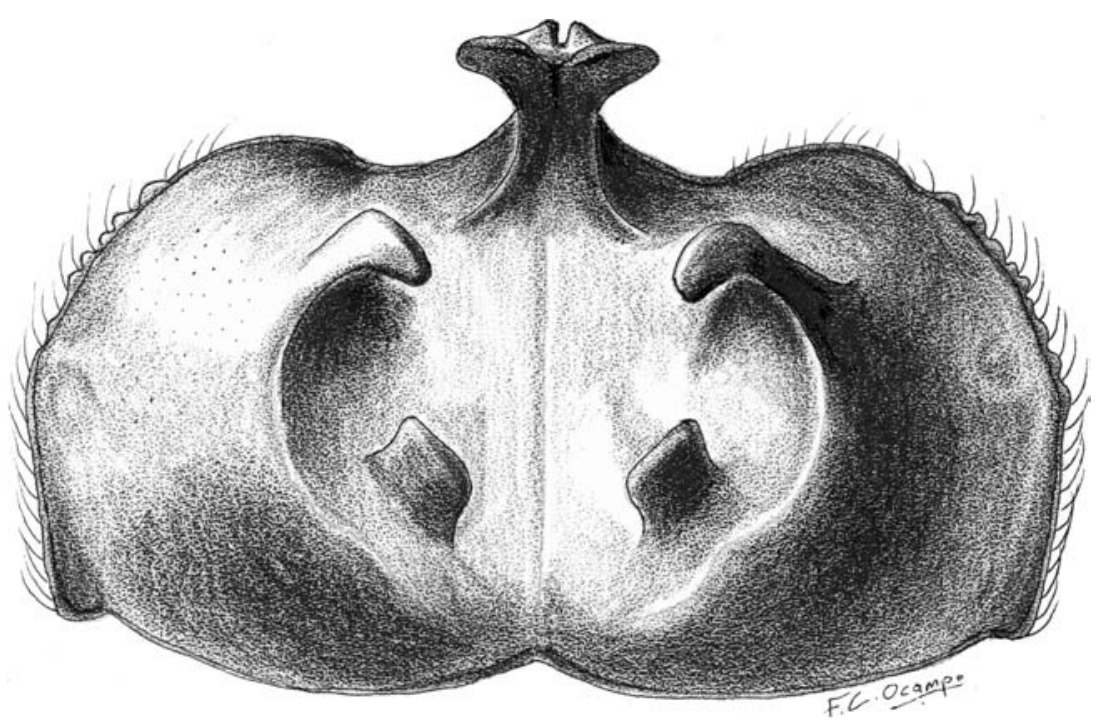

Fig. 5. Dorsal view of the pronotum of Glyphoderus sterquilinus (Westwood).

used to "calculate" the direction to the burrow. When the entrance of the burrow is reached, the beetles enter by walking forward rather than backward. Observations published by Zunino et al. (1989) regarding the above behavioral character, suggested that the beetles drop the dung pellet turn back, and enter the nest walking backward dragging the pellet. I have not observed this for any Eucraniini species (see Ocampo 2003). The burrow is always previously dug. It is variable in depth (usually between $0.25-1 \mathrm{~m}$ long) and variable in slope (between $35-60^{\circ}$ with respect to ground surface). The tunnel may be straight or curved. The depth of the burrow is apparently dictated by the level of soil moisture. Burrows are sometimes bifurcated near the end. The beetles store the food at the end of the burrow and no special chamber seems to be prepared for that purpose. Usually between 3-10 dung pellets are stored, and each pellet is carried independently. Sexual cooperation has been observed and it follows the same behavior as that observed for individuals. No special brood chambers were observed in burrows constructed by pairs. During the hours where there is no surface activity, it is common to observe the entrance of the burrow obscured with sand or the available substrate.

Observations of the food relocation behavior of $G$. centralis were conducted by Zunino et al. (1989) in La Rioja, Argentina. According to Zunino et al. (1989) this species is mostly active during day between 9:00-11:00 am and sporadically between 4:30-5:30 pm at temperatures between $18-37^{\circ} \mathrm{C}$. This species occurs in open sandy areas that are mostly devoid of grass cover. Food preferences are almost exclusively dry rodent pellets from: "vizcacha" (Lagostomus maximus (Desmarest)), "mara" (Dolichotis patagonum (Zimmermann)), "conejo de palo" (Pediolagus salinicola (Burmiester)), and rarely dehydrated cow dung.

\section{Key to Species of Glyphoderus}

1 Pronotum with two transversally elongated tubercles on apical half and two horns in middle (Fig. 3) Glyphoderus centralis Burmeister 


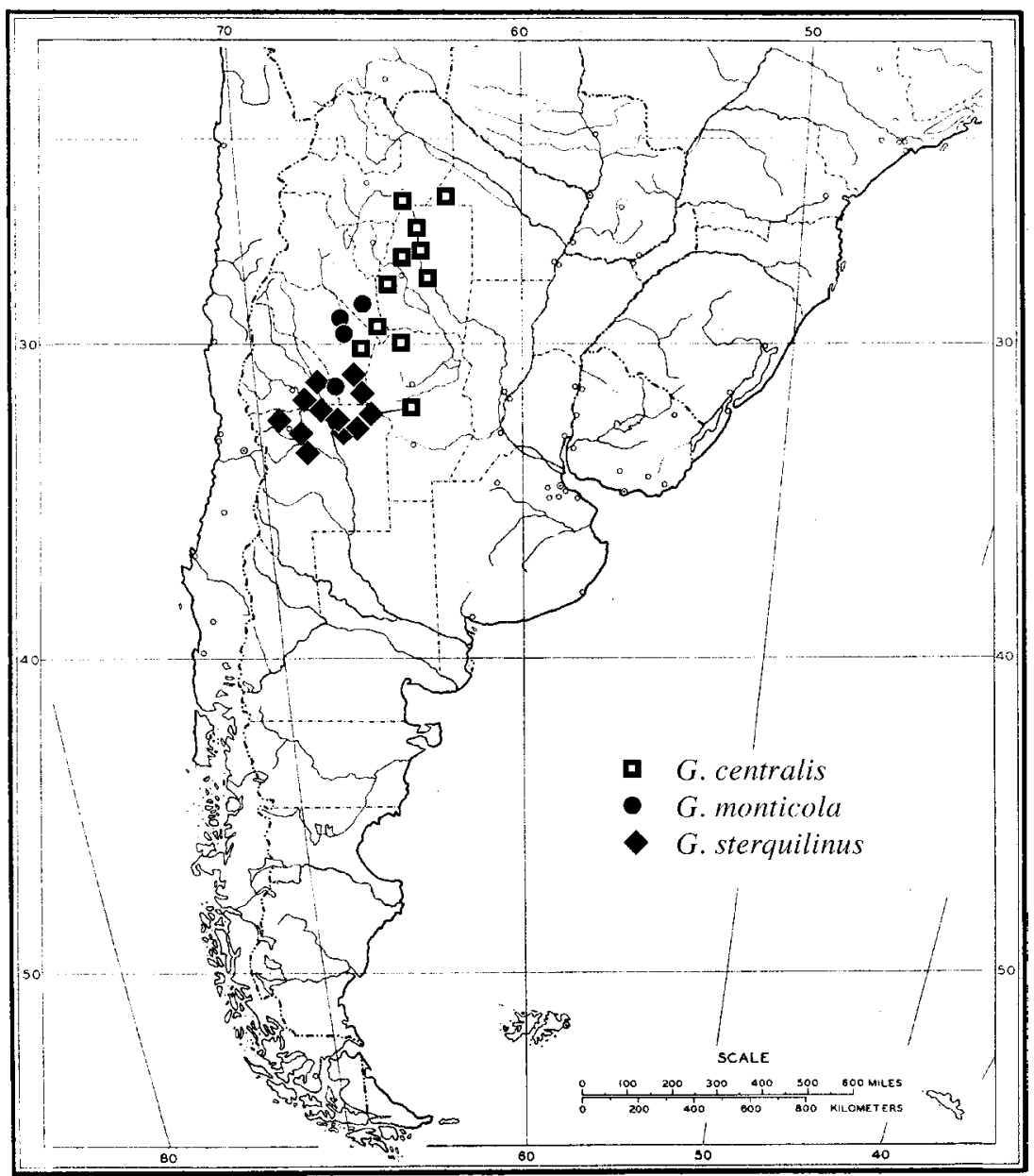

Fig. 6. Map showing distribution of Glyphoderus species.

$1^{\prime}$ Pronotum with two horns in middle and two transversally elongated tubercles (sometimes developed as horns) on the basal half

2 Pronotal horns and tubercles on margin of medial depression (Fig. 4) Glyphoderus monticola Burmeister

$2^{\prime}$ Pronotal horns on margin of central depression and tubercles of basal half included in central depression (Fig. 5) Glyphoderus sterquilinus (Westwood)

\section{Clave para las Especies de Glyphoderus}

1 Pronoto con dos tubérculos alargados transversalmente en la mitad apical y dos cuernos en el medio (Fig. 3)

Glyphoderus centralis Burmeister

$1^{\prime}$ Pronoto con dos cuernos en el medio y dos tubérculos alargados transversalmente (a veces desarrollados como cuernos) en la mitad basal 
2 Cuernos y tubérculos del pronoto en el margen de la depresión central (Fig. 4) Glyphoderus monticola Burmeister

2' Cuernos del pronoto en el margen de la depresión central; tubérculos del pronoto incluidos en la depresión central (Fig. 5) ... Glyphoderus sterquilinus (Westwood)

\section{Glyphoderus centralis Burmeister, 1873}

(Figs. 3, 6)

Glyphoderus centralis Burmeister, 1873:407.

Diagnosis. Males. This species is separated from other Glyphoderus species by the shape and placement of the pronotal horns and tubercles (Fig. 3). Glyphoderus centralis has the pronotum with two transversally elongated tubercles on apical half and two horns in middle; horns and tubercles on margin of central depression; anteromedial horn with "arms" robust, with medial anterior notch. No morphological characters were found to diagnose females of this species, females can be identified only by association with males.

Distribution (Fig. 6). ARGENTINA: Chaco: Taco Pozo (1); Salta: Chaco Occidental, Los Colorados (100 km NE) (1); San Luis: Talita (1). Santiago del Estero: Beltrán (2); Choya (21); El Charro (13); Fernández (5); Río Salado (4); San Gregorio (4); Puna (15); no more data (13).

Temporal Distribution. January (3); February (11), March (14), April (1); October (21), November (2), December (17).

Remarks. Zunino et al. (1989) and Martínez (1956) recorded G. centralis from the Argentinean provinces of Catamarca, Córdoba, La Rioja, and Tucumán. Though I did not study specimens from these provinces I believe that they should be considered as part of the distributional range.

\section{Glyphoderus monticola Burmeister, 1861}

(Figs. 2, 4, 6)

\section{Glyphoderus monticola Burmeister, 1861:67.}

Diagnosis. Males. This species is separated from other Glyphoderus species by the shape and placement of the pronotal horns and tubercles (Fig. 4). Glyphoderus monticola has the pronotum with two horns in middle and two transversally elongated tubercles (sometimes developed as horns) on the basal half; horns and tubercles on margin of medial depression; anteromedial horn with "arms" elongated, with two anteromedial teeth; distance between teeth as long as tooth base. No morphological characters were found to diagnose females of this species, females can be identified only by association with males.

Distribution (Fig. 6). ARGENTINA: Catamarca: El Recreo (3). La Rioja: La Rioja (3); La Rioja (20 km N) (4); Mascasin (33); no more data (2).

Temporal Distribution. January (31), February (4), March (3), November (2), December (1).

\section{Glyphoderus sterquilinus (Westwood, 1837)}

(Figs. 5, 6)

Glyphoderus sterquilinus (Westwood, 1837):13.

Anomiopsis sterquilinus Westwood, 1837:13. Original combination. 
Diagnosis. Males. This species is separated from other Glyphoderus species by the shape and placement of the pronotal horns and tubercles (Fig. 5). Glyphoderus sterquilinus has the pronotum with two horns in middle and two transversally elongated tubercles (sometimes developed as horns) on basal half; horns on margin of central depression; tubercles of basal half included in central depression; apical medial horn with "arms" robust, with anteromedial notch. Some specimens of G. sterquilinus have the posterior pronotal tubercles on the central depression margin (observed particularly in minor males), in this case, the shape of the medial horn will separate this species from G. monticola (Figs. 4, 5). No morphological characters were found to diagnose females of this species, females can be identified only by association with males.

Distribution (Fig. 6). ARGENTINA: Mendoza: Las Catitias (7 km S) (6); Santa Rosa (1); Villavicencio (1). La Rioja: Chepes (2); Ulapes (17 km S) (28); Ulapes (10 km N) (8). San Juan: Encón (12 km E) (1); Nikizanga (2); Morayes -Astica road (1). San Luis: Jarilla (1); La Chañarienta (2); San Antonio (5); Talita (8); no more data (11). Santiago del Estero: No more data (6).

\section{Acknowledgments}

I thank Brett Ratcliffe and Mary Liz Jameson (University of Nebraska, Lincoln) for their critical review of the manuscript. I am grateful to Lee Herman (American Museum of Natural History, New York, NY), Robert Anderson and François Génier (both at the Canadian Museum of Nature, Ottawa, Canada), Andrew Davies (Canadian National Collection of Insects, Ottawa, Canada), Henry Howden (Ottawa, Canada), Sergio RoigJuñent (Instituto Argentino de Investigaciones de Zonas Aridas), Darren Mann (Hope Entomological Collections Oxford, England), Axel Bachmann (Museo Argentino de Ciencias Naturales, Buenos Aires, Argentina), Juan Schnack and Alberto Machala (both at the Museo de La Plata, La Plata, Argentina), Karla Schneider (Martin-LutherUniversität, Zoologisches Institut, Halle, Germany), Jean Menier (Muséum National d'Historie Naturelle, Paris, France), and Nancy Adams (United States National Museum, Washington D.C.) for loans of specimens. I would like to thank Sergio RoijJuñent (Instituto Argentino de Investigaciones de Zonas Aridas) and David Gorla (Centro Regional de Investigaciones Científicas y Transferencia Tecnológica, La Rioja) for their help, hospitality, and logistic support during my field trips in Argentina. This project was supported by an NSF/PEET grant (DEB-0118669) to Mary Liz Jameson and Brett Ratcliffe, by an NSF Biotic Surveys and Inventory grant (DEB 9870202) to Brett Ratcliffe, and by a Graduate Student Research Support from the Initiative for Ecological and Evolutionary Analysis (IEEA) at UNL.

\section{Literature Cited}

Blackwelder, R. E. 1944. Checklist of the coleopterous insects of Mexico, Central America, the West Indies, and South America, Parts 1-6. Bulletin of the United States National Museum 185:1-1492.

Bruch, C. 1911. Catálogo sistemático de los coleópteros de la República Argentina IV. Revista del Museo de La Plata 17:181-225.

Burmeister, H. 1961. Die ateuchiden ohne fulskrallen, monographisch bearbeitet. Berliner Entomologische Zeitschrift 5:55-67.

Burmeister, H. 1973. Lamellicornia Argentina. Stettiner Entomolgische Zeitung 34:403-417.

Byrne, M., M. Dacke, P. Nordström, C. Scholtz, and E. Warrant. 2003. Visual cues used by ball-rolling dung beetles for orientation. Journal of Comparative Physiology (published on line) 10.1007/s00359-003-0415-1.

Cabrera, A. L. 1976. Regiones Fitogeográficas de Argentina. Enciclopedia Argentina de Agricultura y Jardinería. Tomo II. Fascículo I. Editorial ACME S.A.C.I. 85 pp. 
Colomba, M. S., E. Monteresino, R. Vitturi, and M. Zunino. 1996. Characterization of mitotic chromosomes of the scarab beetles Glyphoderus sterquilinus (Westwood) and Bubas bison (L.) (Coleoptera: Scarabaeidae) using conventional and banding techniques. Biologisches Zentralblatt 115:58-70.

Dacke, M., and E. Warrant. 2002. Navigation using polarized light in dung beetles. http:// www.biol.lu.se/funkmorf/vision/dan/dung.html. Accessed day: May 2003.

Gemminger, M., and E. von Harold. 1869. Catalogus coleopterorum hucusque descriptorum synonymicus et systematicus 4:979-1346.

Gillet, J. J. E. 1911. Pars 38. Scarabaeidae: Coprinae. I [pp. 1-100]. In: Coleopterorum Catalogus (S. Schenkling, editor). W. Junk, Berlin.

Halffter, G., and E. G. Matthews. 1966. The natural history of dung beetles of the subfamily Scarabaeinae. Folia Entomológica Mexicana 12-14:1-312.

Morello, J. 1958. La provincia fitogeográfica del monte. Opera Lilloana 2:1-155.

Martínez, A. 1956. Catálogo de los Scarabaeidae argentinos (Coleoptera). Revista del Museo Argentino de Ciencias Naturales Bernardino Rivadavia 5:1-130.

Ocampo, F. C. 2003. Evolution of the food relocation behavior of the dung beetle tribe Eucraniini. http://www-museum.unl.edu/research/entomology/Eucraniini.Eucraniini-1.htm. Accessed day: July, 2003.

Ocampo, F. C. 2004. Revision of the southern South American endemic genus Anomiopsoides Blackwelder 1944 (Coleoptera: Scarabaeidae: Scarabaeinae: Eucraniini) and description of its food relocation behavior. Journal of Natural History (in press).

Phillips, T. K., C. H. Scholtz, and F. C. Ocampo. 2002. A phylogenetic analysis of the Eucraniini (Coleoptera: Scarabaeidae: Scarabaeinae). Insect Systematics and Evolution 33: $241-252$.

Roig-Juñent, S., G. Flores, S. Claver, G. Debandi, and A. Marvaldi. 2001. Monte Desert (Argentina): insect biodiversity and natural areas. Journal of Arid Environments 47:77-94.

Westwood, J. O. 1837. Illustrations of exotic entomology, containing upwards of six hundred and fifty figures and descriptions of foreign insects, interspersed with remarks and reflections on their nature and properties. Proceedings of the Zoological Society of London 5:12-13.

Westwood, J. O. 1838. Description of several new species of insects belonging to the family of the sacred beetles. Transactions of the Zoological Society of London 2:153-164.

Wheeler, Q. D., and N. I. Platnick. 2000. The phylogenetic species concept (sensu Wheeler and Platnick) [pp. 55-69]. In: Species concepts and phylogenetic theory (Q. D. Wheeler and R. Meier, eds.).Columbia University Press, New York.

Zunino, M., E. Barbero, and M. Luzzatto. 1989. Food relocation behavior in Eucraniina beetles (Scarabaeidae) and the constraints of xeric environment. Tropical Zoology 2:235-240.

Zunino, M., E. Barbero, C. Palestrini, and M. Luzzatto. 1991. La taxocenosi a Scarabaeidi coprofagi xerico: materiali per un'analisi biogeografica storico-causale. Biogeographia 15: $41-47$.

(Received 26 September 2003; accepted 13 November 2003. Full page charges borne by the author. Publication date 13 July 2004.) 